\title{
FDI and Economic Growth: Causality for the EU and ASEAN
}

\author{
Argiro Moudatsou \\ Technological Educational Institute of Crete \\ Dimitrios Kyrkilis \\ University of Macedonia
}

\begin{abstract}
This study attempts to address the causal-order between inward FDI and economic growth using a panel data set for two different Economic Associations that is $\boldsymbol{E U}$ (European Union) and ASEAN (Association of South Eastern Asian Nations) over the period 1970-2003. The inflows of FDI to developed host countries raise the question of how these inflows affect their economies and what is the interaction between FDI and growth. While there is considerable evidence on the link between FDI and Economic Growth, the causality between them has not been investigated in a reasonable procedure. Three possible cases are investigated in this paper 1) Growth-driven FDI, is the case when the growth of the host country attracts FDI 2) FDI-led growth, is the case when the FDI improves the rate of growth of the host country and 3) the two way causal link between them. Empirical results obtained from heterogeneous panel analysis indicate the following. Regarding the $\boldsymbol{E} \boldsymbol{U}$ countries the results support the hypothesis of GDP -FDI causality (growth driven FDI) in the panel. Regarding the ASEAN, there is a two-way causality between GDP per capita and FDI like the cases of Indonesia and Thailand. In the cases of Singapore and the Philippines, howerver, FDI is motirated by host country's. GDP growth. So, the

\footnotetext{
*Corresponding address: Argiro Moudatsou: Technological Educational Institute of Crete, Markou Avgeri 3, 71202 Heraklion Crete- Greece, Tel: 302810 284682, E-mail: moudatsou@sdo.teicrete.gr. / Dimitrios Kyrkilis: University of Macedonia, Egnatia 156, P.O. Box 1591, Thessaloniki, Greece 54006 , Tel: +30 2310 891473, E-mail: kyrkilis@uom.gr.

(c)2011-Center for Economic Integration, Sejong Institution, Sejong University, All Rights Reserved.
} 
resullts are path dependent and country-specific.

- JEL Classification: F21, F23,O52

- Keywords: Foreign Direct Investment, Economic Growth, Cointegration, Errorcorrection models and Causality

\section{Introduction}

Foreign Direct Investment (FDI) patterns may be explained within the framework of the eclectic paradigm ${ }^{1}$, which states that at a certain point in time a firm's decision to engage in international production ${ }^{2}$ is taken upon the configuration of three types of determinants. First, ownership specific (O) advantages, name under which they are classified technology, know-how, and other tangible and intangible resources exclusively possessed by the firm and able to generate a flow of income. Second, internalization (I) advantages that describe the extent to which it is advantageous for the owning firm to utilize its resources either via a contractual mode of international production, e.g. licensing, franchising, etc. or via undertaking international trade and/or creating an internal market, i.e. establishing a subsidiary abroad, which means via undertaking FDI. Third, location (L) advantages, which include natural resources and/or created endowments, existed in foreign locations that complement the firm's $(\mathrm{O})$ advantages. The combination of $(\mathrm{L})$ and $(\mathrm{O})$ advantages via local production at the foreign site, given that the (I) advantages do exist generates value added to the firm greater than the one generated via international trade, and, hence, the configuration of specific OLI advantages proves FDI more beneficial than any other mode of international production.

Economic theory suggests a number of factors that may constitute location advantages. Such factors are both market size and growth, production costs, availability of natural resources, availability of an educated and trained labour force with adequate skills and specialisations, an institutional framework that guarantees a pro business climate, well organised money and credit markets, well defined property rights, low transaction costs, etc. as well as factors related to geography, history and culture, political stability and attitudes. Empirical research consolidates a consensus over the significance of market size and growth in motivating FDI.

${ }^{1}$ See Dunning (1977, 1979, 1980, 1993, 2001).

${ }^{2}$ International production includes activities such as international trade, licensing, and FDI. 
The latter takes place in imperfect markets that give rise to $(\mathrm{O})$ advantages as means of coping with competition through raising barriers to entry. ${ }^{3}$ In turn, the markets of $(\mathrm{O})$ advantages are imperfect preventing the possessing firm from receiving the full rent of the utilisation of these resources via an arm's length market transaction, ${ }^{4}$ thus raising (I) advantages and leading to the choice of FDI as the mode of foreign engagement. Product differentiation through the application of extensive $R \& D$ is the main form of $(\mathrm{O})$ advantages, and it may be effectively undertaken by firms that possess able financial and human resources, i.e. large firms operating in developed markets. Differentiated products are sold on the basis of high income elasticity of demand, pertaining to developed markets of high average incomes and of highly differentiated demand patterns. Product differentiation becomes efficient by the co-existence of cost competitiveness based on the exploitation of economies of scale mainly pertained to large markets. Therefore, large markets of increasing per capita purchasing power are both the source and host countries of FDI.

The configuration of existing OLI advantages at a specific point in time may be considered as a rather static condition. Therefore, the determination of the mode of foreign production it provides is also static. Within this frame, FDI may be considered as market growth induced, and to the extent that market growth is dependent upon the economic growth of a country FDI may be considered as economic growth induced. Economic growth, though, is a dynamic concept, and it evolves over time. The relationship between FDI and economic growth should be seen in this intertemporal dynamic. The investment development path (IDP) analytical framework presents an attempt to introduce the economic growth dynamics in the analysis of FDI patterns.

The IDP is based upon Rostow's model of economic growth. According to Rostow economic growth proceeds in stages in a linear mode that is universal. Economic growth in all countries would follow the same evolution path through four stages. ${ }^{5}$ Each stage of economic growth has certain characteristics, which Dunning considers as location advantages of the country going through the specific economic growth stage, therefore, they determine the type of FDI expected to come into the country and at the same time they induce local firms to generate $(\mathrm{O})$

\footnotetext{
${ }^{3}$ See Hymer (1976); Kindlemberger (1969); Caves (1971); Hood and Young (1979).

${ }^{4}$ For the theory of transaction costs see Coase (1937) Williamson (1975) and for the use of the theory to the issue of FDI see Buckley and Casson (1976).

${ }^{5}$ See Rostow (1959).
} 
advantages, which in turn and in conjunction with the (I) advantages determine the propensity of local firms to invest abroad. Each stage of economic growth is characterised by a set of political, cultural and economic conditions particular to individual countries, which determines the configuration of OLI advantages of the country in question, and in turn the net, i.e inward minus outward FDI position of the specific country. ${ }^{6}$ In that respect, the IDP is idiosyncratic, i.e. country specific in nature, meaning that each country follows a unique self dependent path influenced by the development of four main variables. ${ }^{7}$ First, the structure of natural resource assets facilitates investments in the exploitation of such assets. Second, the market size supporting economies of scale. Third, the economic system as it differentiates between an export outward looking economic orientation and an import substituting inward-looking economic orientation. Fourth, government's policy and the organisation of economic activity imply the macroeconomic policy and the macro-organisation strategy facilitating the function of markets, and regulating transaction costs.

The first stage of economic growth is characterized by very low capital accumulation, low per capita incomes, inadequate markets in terms of size and organization, inadequate infrastructure, poorly skilled labour force, and, in general, insufficient (L) advantages for motivating inward FDI and equally insufficient (O) advantages prohibiting indigenous firms to engaging in international production. In stage two capital accumulation rises, domestic demand grows, both industrialization and infrastructure building proceed, labour has achieved a minimum threshold of education and has acquired some basic skills factors that facilitate the efficient introduction and operation of standardized technology allowing productivity to rise while labour costs are relatively low. The latter is at the centre of the country's location advantages, and the main motivation for inward FDI. At the same time, the $(\mathrm{O})$ advantages of indigenous firms are still insufficient to support engagement in outward FDI, although exporting of low technology labour intensive goods may occur. In stage three, rising personal incomes differentiate domestic consumer demand toward products of higher quality; rising wages deteriorate the low labour cost advantage motivating indigenous firms to undertake outward FDI in foreign sites of even lower wages while advancing technological capabilities are restructuring domestic production towards industries producing capital intensive

${ }^{6}$ See Dunning (1981, 1986, 1988, 1993).

${ }^{7}$ See Narula (1996). 
and standardized goods. The motives of inward FDI change from taking advantage of low wages to taking advantages accruing from enlarged market size, advanced technological abilities, and skilled workers, existence of complementary local supply chains, etc. In general, inward FDI becomes increasingly efficiency seeking an orientation aiming at achieving economies of scale and scope through a regionally vertically or horizontally integrated production and marketing network. ${ }^{8}$ In this case, the existence or formation of a regional economic integration structure allowing free trade between the member states benefits the inflow of FDIs locating diffrent production phases to individual member states according to peculiar (L) advantages differentiated between the same member states. The best example of this case is the European Union. ${ }^{9}$ In stage four, indigenous firms develop (O) advantages similar to those possessed by foreign firms investing in the country, i.e. proprietary created assets, but still they lack information intensive technology. Outward FDI is increasing due to the rising ability of domestic firms to exploit their $(\mathrm{O})$ advantages via internal modes while inward FDI continuous to be efficiency seeking, but because host country firms are able to compete with them effectively the pace of incoming FDI is slowing down. Governments pursue a policy of lowering transaction costs, supervising and regulating markets aiming at reducing market failure, and facilitating the readjustment of (L) advantages towards technology creation and knowledge accumulation. Dunning has added a fifth stage to the original four stages of Rostow's model. In the fifth economic growth stage countries are increasingly engaged in generating knowledge, information intensive technology, highly skilled human capital, and efficiently organized markets. Both outward and inward FDI is both efficiency and strategic assets seeking implying that cross border production and exchange take place within hierarchical multinational structures producing similar products and being in direct competition. The implication of the increasing importance of strategic asset seeking FDI is that FDI activity is linked with the acquisition of $(\mathrm{O})$ advantages, which are firm specific by their very nature, therefore any spillover effect is transferred back to the parent company, thus reducing spillovers to the host economy and increasing spillovers back home. In stage 5, outward FDI tends to balance inward FDI as countries are converging making FDI patterns increasingly integrated. That way FDI activity both inward and outawrd of the group of countries clustering in stage

${ }^{8}$ See Narula (1996) pp. 14-15.

${ }^{9}$ There is considerable literature on the subject. Indicatively see Pantelidis and Kyrkilis (2006); Dunning (1997); Pain and Lansbury (1997); Thomsen and Woolock (1993); UNCTC (1990). 
five is interrelated and commonly motivated, and it fluctuates around an equilibrium determined by a rather common set of OLI advantages.

The above stated IDP model may be reformulated in a dynamic context. The evolution of (L) advantages, which may be partly induced by government policy triggers the evolution of both $(\mathrm{O})$ and $(\mathrm{I})$ advantages ending to a new configuration of OLI advantages for the particular country influencing the restructuring of both inward and outward FDI patterns of the country in question. The evolution of FDI patterns, given that FDI transfers across countries resources and capabilities affects the OLI advantages. Multinationality of firms per se creates and advances capabilities over the use and control of resources across disperse geographical regions generating that way new $(\mathrm{O})$ and $(\mathrm{I})$ advantages. The interaction between the evolving configuration of OLI advantages in the process of economic growth of a specific country and the correspondingly evolving FDI patterns of the same country makes both FDI and economic growth for this particular country path dependent.

At a given time period $t_{0}$ a country possesses a set of location advantages $\mathrm{L}_{\text {to }}$ and it attracts FDI possessing certain ownership advantages $\mathrm{O}_{\text {to }}$ and utilizing particular internalization advantages $\mathrm{I}_{\mathrm{to}}$. The transferred $(\mathrm{O})$ advantages may upgrade existing local resources, induce changes in the demand conditions, trigger spillovers, mainly of technological nature to support and related industries, contribute to the accumulation of technology that in turn, through a gradual process creates new technological inputs. Therefore, the whole process leads to the development of the (O) advantages, and to the evolution of the set of (L) advantages of the host country. At the same time government policies aiming at protecting intellectual property rights, promoting exports and $\mathrm{R} \& \mathrm{D}$ activities, regulating markets and reducing transaction costs, etc. affect the configuration of OLI advantages. Overall, in time period $t_{1}$ an evolved set of $\mathrm{O}_{\mathrm{t} 1} \mathrm{~L}_{\mathrm{t} 1} \mathrm{I}_{\mathrm{t} 1}$ advantages of the host country is present generating another pattern of FDIs both inward and outward that may trigger a new round of OLI advantages evolution in time $t_{2}$, which in turn creates new patterns of FDIs, and the process goes on.

The notion of an investment -development path puts forward the idea that the outward and inward FDI position of a country is systematically related to its economic growth. Particular stages of economic growth of a country are characterised by a particular configuration of OLI advantages that determine both inward and outward FDI patterns of the specific country, which in turn influence the OLI configuration of advantages advancing economic growth and determining 
the new round of FDI patterns. This process is both country idiosyncratic and path dependent, i.e. different countries are related to different patterns of the interrelationship between FDI and economic growth, although some generalisation may be observed due to the procession of countries through the same stages of economic growth with each stage presenting some common features between countries. The aim of this paper is to empirically examine the interrelation between FDI and economic growth as it evolves over time. More specifically, the aim is to test for the causal relationship between FDI flows and economic growth for two different groups of countries belonging to certain regional economic integration structures. The first group is comprised by developing countries, which are members of the Association of South East Asian Nations (ASEAN) and the second group contains a number of developed countries, which are members of the European Union (EU). The idea is to compare the empirically identified relationship between these two different country groups. Inspired by previous results about the impact of FDI on growth the paper seeks to identify systematic patterns in the size of the long run impact of FDI on GDP and/or the opposite, and, in addition to relate the direction of impact on the economic and technological conditions of host countries ${ }^{10}$ as they differentiate between developed and developing countries.

The hypothesis is that each country may record a two way causal relationship between economic growth, as it is approximated by increases of per capita income, and FDI, approximated by annual inflows of FDI as a share of the host country annual fixed capital formation. Incoming FDI is economic growth induced and in turn it triggers economic growth. However, because of the country idiosyncratic nature of the interrelationship between FDI and economic growth this causal relationship may be different across countries being either FDI induced economic growth or economic growth induced FDI. Because the relationship between FDI and economic growth in any case is country path dependent the relationship between FDI and economic growth for a specific country is expected to be systematic over time. An additional assumption may be that countries belonging to the same regional economic association are becoming increasingly integrated over time, thus they are converging to the same economic growth stage and to some common economic structures and policies. FDI patterns are also expected to converge between countries of the same regional economic association. Therefore,

\footnotetext{
${ }^{10}$ See De Mello (1997).
} 
the interrelationship between economic growth and FDI in each regional economic association is expected to be realised through similar dynamic processes, thus its causality is expected to be of the same direction.

\section{Empirical Evidence and Interpretations}

During the last decade a number of interesting studies of the role of foreign direct investment in stimulating economic growth has appeared. De Mello (1997) lists two main channels through which FDI may be growth enhancing. First, FDI can encourage the adoption of both new technologies in the production process and new products through technological spillovers made possible via a demonstration and/or a competition effect. Second, FDI may stimulate knowledge transfers, both in terms of labour training and skill acquisition and by introducing alternative management practices and better organizational arrangements. In addition to the above described horizontal spillovers, i.e. within the same industry, vertical spillovers, i.e. iner-industry may be also observed. Foreign companies may transfer technology, and set higher requirements regarding product quality and on time delivery to local suppliers in order to increase the quality of intermediate inputs they purchase from them. The establishment of foreign subsidiaries increases the demand for intermediate inputs allowing domestic suppliers to exploit economies of scale and/or encouraging the entry of new producers. ${ }^{11}$ Besides, availability of high technology intermediate goods supplied by foreign subsidiaries may advance the product quality, hence the competitiveness of domestic downstream industries. A survey by OECD (2002) underpins these observations and documents that 11 out of 14 studies have found FDI to contribute positively to income growth and factor productivity.

However, horizontal spillovers may be difficult to occur due to precautions foreign multinationals take in order to prevent their superior technology and Knowhow to leak to their domestic competitors either issuing patents or applying to their employees' remuneration packages relatively more attractive than indigenous companies are in a position to offer. Multinationals may also operate in market segments quite distinct from indigenous firms in terms of technology and product specialisation. In cases they compete directly with local suppliers they may

\footnotetext{
${ }^{11}$ See Rivera Batiz and Rivera Batiz (1990) and Markusen and Venables (1999).
} 
marginalise them using their superior competitiveness ${ }^{12}$ and their ability to hire the rather more qualified employees paying better wages. Foreign subsidiaries, in their search for product quality they may divert demand for intermediate inputs away from local producers and in favour of foreign suppliers including other subsidiaries belonging to the parent's company multinational production and marketing network. That way foreign investment may raise barriers to market entry to domestic firms, and generate a crowding out effect to indigenous investments while it limits markets competition reducing efficiency.

Both de Mello and OECD stress one key insight from all studies reviewed: the way in which FDI affects growth is likely to depend on the economic and technological conditions in the host country. In particular, it appears that developing countries have to reach a certain level of development, in education and/or infrastructure, before they are able to capture potential benefits associated with FDI. Hence, FDI seems to have more limited growth impact in technologically less advanced countries.

Four studies, relying on a variety of cross-country regressions, have looked into the necessary conditions for identifying a positive impact of FDI on economic growth. Interestingly, they stress different, though closely related, aspects of development. First, Blomström et al. (1994) argue that FDI has a positive growtheffect when a country is sufficiently rich in terms of per capita income. Second, Balasubramanyam et al. (1996)

emphasise trade openness as being crucial for acquiring the potential growth impact of FDI. Third, Borenztein et al. (1998) find that FDI raises growth, but only in countries where the labour force has achieved a certain level of education. Finally, Alfaro et al. (2004) draw attention to financial markets as they find that FDI promotes economic growth in economies with sufficiently developed financial markets. However, when Carkovic and Levine (2002) estimate the effects of FDI on growth after controlling for the potential biases induced by endogeneity, country-specific effects, and the omission of initial income as a regressor, they find that the results of these four papers break down. Carkovic and Levine conclude that FDI has no impact on long run growth.

Another strand of the literature has focused more directly on the causal

\footnotetext{
${ }^{12}$ Multinationals employ the most advanced technology and Know-how investing heavily in R\&D. Borensztein et al. (1998) argue that multinationals account for a significant part of world's R\&D and they have higher rates of innovation and acquisition of patents in comparison with solely national firms. Thus they achieve higher competitiveness relatively to existing and potential national firms.
} 
relationships between FDI and growth and, at least, six studies have tested for Granger causality between the two series using different samples and estimation techniques. Zhang (2001) looks at 11 countries on a country-by-country basis, dividing the countries according to the time series properties of the data. Tests for long run causality based on an error correction model, indicate a strong Grangercausal relationship between FDI and GDP-growth. For six counties where there is no co-integration relationship between the log of FDI and growth, only one country exhibited Granger causality from FDI to growth. Chowdhury and Mavrotas (2003) take a slightly different route by testing for Granger causality using the Toda and Yamamoto (1995) specification, thereby overcoming possible pre-testing problems in relation to test for co-integration between series. Using data from 1969 to 2000, they find that FDI does not Granger cause GDP in Chile, whereas there is a bidirectional causality between GDP and FDI in Malaysia and Thailand. De Mello (1999) looks at causation from FDI to growth in 32 countries of which 17 are nonOECD countries. First he focuses on the time series aspects of FDI on growth, finding that the long run effect of FDI on growth is heterogeneous across countries. Second, de Mello complements his time-series analysis by providing evidence from panel data estimations. In the non-OECD sample he finds no causation from FDI to growth based on fixed effects regressions with country specific intercepts, and a negative short run impact of FDI on GDP using the mean group estimator.

Nair-Reichert and Weinhold (2001) test causality for cross country panels, using data from 1971 to 1995 for 24 countries. Like de Mello, they emphasize heterogeneity as a serious issue and, therefore, use what they refer to as the mixed fixed and random (MFR) coefficient approach in order to test the impact of FDI on growth. The MFR approach allows for heterogeneity of the long run coefficients, thereby avoiding the biases emerging from imposing homogeneity on coefficients of lagged dependent variables. They find that FDI on average has a significant impact on growth, although the relationship is highly heterogeneous across countries.

Choe (2003) uses the traditional panel data causality testing method developed by Holtz-Eakin et al. (1988) in a data set of 80 countries. His results points towards bi-directional causality between FDI and growth, but he finds the causal impact of FDI on growth to be weak. Basu et al. (2003) addresses the question of the twoway link between growth and FDI. Allowing for country specific co integrating vectors as well as individual country and time fixed effects they find a co integrated relationship between FDI and growth using a panel of 23 countries. 
Basu et al. emphasise trade openness as a crucial determinant for the impact of FDI on growth, as they find two-way causality between FDI and growth in open economies, both in the short and the long run, whereas the long run causality is unidirectional from growth to FDI in relatively closed economies.

Hansen and Rand (2004) using a sample of 31 developing countries and using estimators for heterogeneous panel data, found a bi-directional causality between FDI/GDP and the level of GDP. They interpret this result as evidence in favour of hypothesis that FDI has an impact on GDP via knowledge transfers and adoption of new technology. MAhmoud Al-Iriani and Fatima Al-Shami (2007) testing for the relationship between FDI and growth in the six countries comprising the Gulf Cooperation and using heterogeneous panel analysis methods indicate a bidirectional causality. Their results support the endogenous growth hypothesis for this group of countries.

Summing up, the main message to take from this selective survey is that there seems to be a strong relationship between FDI and growth. Although the relationship is highly heterogeneous across countries subject to idiosyncratic conditions of individual countries, the studies generally agree that FDI, on average, has some impact on growth in the Granger causal sense. The main exception from this general conclusion is Carkovic and Levine (2002).

\section{Variables, Data, and Empirical Methodology}

This paper estimates the causality between FDI and economic growth in two country groups. First, the EU group comprised by all current member countries except the newly acceded transition countries, i.e. Austria, Belgium, Cyprus, Denmark, Finland, France, Germany, Greece, Ireland, Italy, Malta, the Netherlands, Portugal, Spain, Sweden, and United Kingdom. The transition countries are not considered because their history of inward FDI is short starting in 1989 the year transition from central plan to market economy was initiated, thus not being compatible with the other countries of the group. In addition, economic transition per se generates conditions and requires policies that may affect the relationship between FDI and economic growth while economic development in transition countries diverges significantly below the average level of the other EU countries increasing the heterogeneity of the group. Nevertheless, it should be noted that not all of the current non- transition EU member countries joined the EU at the same time. That differentiates the economic environment in which FDI inflows to a 
country took place before its accession to the EU from the one established after. The regional integration process following entry to the EU and the consequent common market, economic convergence, even monetary union may have implications for the level and motives of inward FDI to individual countries and to the sources of domestic growth, hence, it may have some distinct impact on the relationship between FDI and economic growth for these countries.

The second group is comprised by developing countries members of the ASEAN, namely Indonesia, Singapore, the Philippines, and Thailand. The remaining ASEAN member countries, i.e. Malaysia, Brunei, Lao, Myanmar, Cambodia and Vietnam are not considered because for a long part of the investigation period, i.e. 1970-2003 were not host countries to foreign investments being either communist countries, in some cases at war or politically unstable, and in any case closed to the international market.

Economic growth is approximated by the Gross Domestic Product (GDP) per capita of country $i$ at a particular time t. GDP per capita is chosen because it is considered a rather appropriate proxy for the level of economic development measuring the latter subject to population, therefore, it normalises economic development by the country size. FDI is approximated by the ratio of FDI inflows to country $i$ at a time $t$ over the Gross Fixed Capital Formation (GFCF) in country $i$ at a time t. This proxy is chosen in order to take into account the significance of FDI in the investment activity of a country.

The data used are annual and they are sourced in the International Monetary Fund (IMF) and PENNTABLES databases.

The estimation is conducted performing the following tests. First, the unit root for series stationarity is performed; second, the order of integration of the economic growth and FDI time series is tested using the Johansen's approach. Then, after correcting the time series for stationarity the Johansen (1988) cointegration test is performed for the economic growth and FDI variables. Finally, in order to detect the direction of causality between economic growth and FDI, the technique of Error Correction Mechanism is applied.

\section{A. Co-integration}

The concept of co-integration was first introduced into the literature by Granger (1980). Co-integration implies the existence of a long-run relationship between economic variables. The principle of testing for co-integration is to test whether two or more integrated variables deviate significantly from a certain relationship 
(Abadir and Taylor, 1999). In other words, if the variables are co-integrated, they move together over time so that short-term disturbances will be corrected in the long-term. This means that if, in the long-run, two or more series move closely together, the difference between them is constant. Otherwise, if two series are not co-integrated, they may wander arbitrarily far away from each other (Dickey et al., 1991).

Further, Granger (1981) showed that when the series become stationary only after being differenced once (integrated of order one), they might have linear combinations that are stationary without differencing. In the literature, such series are called "co- integrated. If integration of order one is implied, the next step is to use co-integration analysis in order to establish whether there exists a long-run relationship among the set of the integrated variables in question. Earlier tests of co-integration include the simple two-step test by Engle and Granger (EG hereafter) (1987). However, the EG method suffers from a number of problems. Alternatively, Engle and Yoo (1987) (EY, hereafter) 3-step procedure have been widely recognized as dealing with most of these problems. Nevertheless, a problem remains which is that both EG and EY methods cannot deal with the case where more than one co-integrating relationship is possible. Hence, Johansen's Vector Auto Regression (VAR) test of integration (Johansen, 1988) uses a 'systems' approach to co-integration that allows determination of up to $r$ linearly independent co-integrating vectors $(\mathrm{r} \leq \mathrm{g}-1$, where $\mathrm{g}$ is the number of variables tested for cointegration). The Johansen's procedure is useful in conducting individual cointegration tests, but does not deal with co-integration test in panel settings. So we applied the test in each country of the sample separately.

\section{B. Causality test}

Having detecting the number of co-integrated equations (Johansen's procedure) an error correction model (ECM) is used for a country by country analysis. (Cointegration necessitates that the variables to be integrated are of the same order). If the variables in the model contain unit roots, the Error Correction Model (ECM) is used to examine the long-run or co-integrating relationships between the time series as well as the existence and the direction of causality between the variables.

The estimated bi-variate ECM for each country takes the following form:

$$
\begin{gathered}
\Delta G_{i t}=\alpha_{0}+\sum \alpha_{l j} \Delta G_{i t-1}+\sum \alpha_{2 j} \Delta F D_{i t-1}+\varphi E C T_{i t-1}+u_{l i t} \\
\left(i=1 \ldots n_{1}\right) \quad\left(i=1 \ldots n_{2}\right)
\end{gathered}
$$




$$
\begin{gathered}
\Delta F D_{i t}=b_{0}+\sum b_{1 j} \Delta F D_{i t-1}+\sum b_{2 j} \Delta G_{i t-1}+\varphi E C T_{i t-1}+u_{2 i t} \\
\left(j=1 \ldots n_{1}\right) \quad\left(j=1 \ldots n_{2)}\right.
\end{gathered}
$$

Where $\Delta$ is the difference operator, $\mathrm{G}_{\mathrm{t}}$ is the GDP per capita, $\mathrm{FD}_{\mathrm{t}}$ is the FDI as percentage to gross fixed capital formation, $\mathrm{ECT}_{\mathrm{it}-1}$ is the error correction term derived from the long- run co-integrating relationship, $\mathrm{u}_{1 \mathrm{t}}$ and $\mathrm{u}_{2 \mathrm{t}}$ are the white noise error terms $t$ denotes the years and $n_{1}, n_{2}$ are the lag orders of $\alpha$ 's and $b$ 's respectively.

The VECM results distinguish between short-run and long-run Granger causality. The coefficients of the lagged error correction term show that there is a long-run causal relationship between economic growth and FDI. It also indicates that FDI and economic growth are adjusting to their long-run equilibrium relationships. (The coefficients and the magnitudes of the ECT indicate the speed of adjustment to the long-run equilibrium relationship). If $\varphi$ is statistically significant in the first equation, but not significant in the second then we say that FDI Granger causes GDP, if the opposite happens we say that GDP Granger causes FDI. If $\varphi$ is significant in both equations we say that there is a bi-directional relationship.

\section{Results}

The ADF tests for stationarity are performed under three hypotheses: The series are stationary at levels (no unit root), at differencing once (one unit root) at differencing twice (two unit roots). Results are reported in Table 1. Both time series, i.e. FDI as a percentage of total gross capital formation and GDP per capita for all countries are integrated either at level one or at level two or both with the exception of FDI as a percentage of total gross capital formation for Malta that has no unit root at all. The level of integration for each time series for all countries under investigation is summarized in Table 2. Tests for co-integration and, consequently for the direction of causality may be run in the case that both variables in question are of the same integration level. Both time series are of the same integration level in the cases of Austria, Denmark, Finland, Germany, Italy, and Sweden for the EU country group while for the ASEAN country group both time series are of the same integration level in all country cases. Therefore, the Johansen test for co-integration is run for the above country cases. The results are 
presented in Table 3. In all the tested country cases the Likelihood Ratio test indicates the existence of two co-integrated equations as it was hypothesized.

Finally, the results of the Error Correction Model Estimation are reported in

Table 1. ADF Unit Root Tests

I) EU Country Group

\begin{tabular}{|c|c|c|c|c|}
\hline \multicolumn{5}{|c|}{ FDI as a share of gross capital formation } \\
\hline COUNTRIES & $\begin{array}{c}\text { ADF-test Stat } \\
\text { (levels) }\end{array}$ & Critical Values* & $\begin{array}{c}\text { ADF-test Stat } \\
\text { (first differences) }\end{array}$ & Critical Values* \\
\hline Austria & -1.554386 & $1 \%-3.6496$ & -7.509674 & $1 \%-3.6576$ \\
\hline Benelux countries & -2.6158418 & $5 \%-2.9558$ & -2.540942 & $5 \%-2.9591$ \\
\hline Cyprus & -0.286010 & $10 \%-2.6164$ & -4.971680 & $10 \%-2.6181$ \\
\hline Denmark & -2.707348 & & -4.421201 & \\
\hline Finland & -0.275617 & & -4.237334 & \\
\hline France & -0.615322 & & -2.255580 & \\
\hline Germany & -2.747181 & & -5.329594 & \\
\hline Greece & -2.041681 & & -5.549542 & \\
\hline Ireland & -0.218447 & & -4.713390 & \\
\hline Italy & -0.961880 & & -4.696550 & \\
\hline Malta & -3.725170 & & -5.025080 & \\
\hline Netherlands & -1.843511 & & -2.705468 & \\
\hline Portugal & -2.768005 & & -5.870211 & \\
\hline Spain & -1.206502 & & -2.677468 & \\
\hline Sweden & -2.324464 & & -4.913177 & \\
\hline UK & -2.502573 & & -3.262850 & \\
\hline \multicolumn{5}{|l|}{ GDP per capita } \\
\hline COUNTRIES & $\begin{array}{l}\text { ADF-test Stat } \\
\text { (levels) }\end{array}$ & Critical Values* & $\begin{array}{c}\text { ADF-test Stat } \\
\text { (first differences) }\end{array}$ & Critical Values* \\
\hline Austria & 0.982394 & $1 \%-3.6496$ & -3.047550 & $1 \%-3.6576$ \\
\hline Benelux countries & 0.984108 & $5 \%-2.9558$ & -2.782051 & $5 \%-2.9591$ \\
\hline Cyprus & 3.030302 & $10 \%-2.6164$ & -2.243639 & $10 \%-2.6181$ \\
\hline Denmark & 2.107952 & & -3.850417 & \\
\hline Finland & -0.161681 & & -3.538711 & \\
\hline France & 0.941398 & & -2.743681 & \\
\hline Germany & 0.150500 & & -3.153133 & \\
\hline Greece & 1.804193 & & -1.256387 & \\
\hline Ireland & 1.157147 & & -1.318191 & \\
\hline Italy & 0.123971 & & -3.591324 & \\
\hline Malta & 0.875070 & & -2.331581 & \\
\hline Netherlands & 0.711970 & & -4.153792 & \\
\hline Portugal & 0.625968 & & -2.427747 & \\
\hline Spain & 1.518367 & & -2.030976 & \\
\hline Sweden & 0.570644 & & -4.181786 & \\
\hline UK & 2.601614 & & -1.883207 & \\
\hline
\end{tabular}


Table 1. ADF Unit Root Tests (continued)

II) ASEAN Country Group

\begin{tabular}{ccccc}
\hline FDI as a share of gross capital formation & \multicolumn{3}{l}{} \\
\hline Countries & $\begin{array}{c}\text { ADF-test Stat } \\
\text { (levels) }\end{array}$ & Critical Values* & $\begin{array}{c}\text { ADF-test Stat } \\
\text { (first differences) }\end{array}$ & Critical Values* \\
\hline Indonesia & -3.294879 & $1 \%-3.6496$ & $\mathbf{- 5 . 6 9 1 4 7 7}$ & $1 \%-3.6576$ \\
Phillipines & -1.997383 & $5 \%-2.9558$ & $\mathbf{- 5 . 1 8 0 2 7 7}$ & $5 \%-2.9591$ \\
Singapore & -2.256608 & $10 \%-2.6164$ & $\mathbf{- 4 . 8 2 6 3 1 0}$ & $10 \%-2.6181$ \\
Thailand & -2.636541 & & $\mathbf{- 4 . 5 9 1 3 6 9}$ & \\
\hline GDP per capita & & & & \\
\hline Countries & ADF-test Stat & Critical Values* & $\begin{array}{c}\text { ADF-test Stat } \\
\text { (first differences) }\end{array}$ & Critical Values* \\
\hline Indonesia & (levels) & & $\mathbf{- 4 . 4 1 4 4 4 4}$ & $1 \%-3.6576$ \\
Phillipines & -0.152891 & $1 \%-3.6496$ & $\mathbf{- 4 . 1 1 4 1 9 3}$ & $5 \%-2.9591$ \\
Singapore & -0.008174 & $5 \%-2.9558$ & $\mathbf{- 4 . 2 2 2 4 4 7}$ & $10 \%-2.6181$ \\
Thailand & 0.121645 & $10 \%-2.6164$ & $\mathbf{- 3 . 0 2 6 8 6 3}$ &
\end{tabular}

Notes: *MacKinnon critical values for rejecting the hypothesis of a unit root at $1 \%, 5 \%$ and $10 \%$ sign level of statistical significance.

Table 2. Integration Order of FDI as a share of Gross Capital Formation and GDP per capita Series

\begin{tabular}{cccccc}
\hline I) EU country group & \multicolumn{5}{c}{ II) ASEAN country group } \\
\hline Countries & FDI & GDP per capita & Countries & FDI & GDP per capita \\
& Series & Series & & Series & Series \\
\hline Austria & I(1) & I(1) & INDONESIA & I(1) & I(1) \\
Benelux countries & I(2) & I(1) & PHILIPPINES & I(1) & I(1) \\
Cyprus & I(1) & I(2) & SINGAPORE & I(1) & I (1) \\
Denmark & I(1) & I(1) & THAILAND & I(1) & I(1) \\
Finland & I(1) & I(1) & & & \\
France & I(2) & I(1) & & \\
Germany & I(1) & I(1) & & \\
Greece & I(1) & I(2) & & \\
Ireland & I(1) & I(2) & & \\
Italy & I(1) & I(1) & & \\
Malta & $\mathrm{I}(0)$ & $\mathrm{I}(2)$ & & \\
Netherlands & $\mathrm{I}(2)$ & $\mathrm{I}(1)$ & & \\
Portugal & $\mathrm{I}(1)$ & $\mathrm{I}(2)$ & & \\
Spain & I(1) & I(2) & & \\
Sweden & I(1) & I(1) & & \\
UK & $\mathrm{I}(1)$ & $\mathrm{I}(2)$ & & \\
\hline
\end{tabular}


Table 3. Johansen Co-integration Test

\begin{tabular}{|c|c|c|c|c|c|}
\hline \multicolumn{6}{|c|}{ I) EU country group } \\
\hline Country & $\begin{array}{c}\text { Hypothesized } \\
\text { number of CEs }\end{array}$ & $\begin{array}{l}\text { Eigen } \\
\text { value }\end{array}$ & $\begin{array}{c}\text { Likelihood } \\
\text { Ratio }\end{array}$ & $\begin{array}{c}5 \% \\
\text { Critical Value }\end{array}$ & $\begin{array}{c}1 \% \\
\text { Critical Value }\end{array}$ \\
\hline \multirow{2}{*}{ Austria } & None & 0.669827 & 43.47432 & 15.41 & 20.04 \\
\hline & At most 1 & 0.254916 & 9.122009 & 3.76 & 6.65 \\
\hline \multirow{2}{*}{ Denmark } & None & 0.405722 & 26.89731 & 15.41 & 20.04 \\
\hline & At most 1 & 0.293370 & 10.76468 & 3.76 & 6.65 \\
\hline \multirow{2}{*}{ Finland } & None & 0.353643 & 23.45245 & 15.41 & 20.04 \\
\hline & At most 1 & 0.273943 & 9.923939 & 3.76 & 6.65 \\
\hline \multirow{2}{*}{ Italy } & None & 0.491263 & 32.70105 & 15.41 & 20.04 \\
\hline & At most 1 & 0.315487 & 11.75048 & 3.76 & 6.65 \\
\hline \multirow{2}{*}{ Germany } & None & 0.531414 & 32.81422 & 15.41 & 20.04 \\
\hline & At most 1 & 0.259543 & 9.315125 & 3.76 & 6.65 \\
\hline \multirow{2}{*}{ Sweden } & None & 0.492835 & 35.08553 & 15.41 & 20.04 \\
\hline & At most 1 & 0.364200 & 14.03902 & 3.76 & 6.65 \\
\hline \multicolumn{6}{|c|}{ II) ASEAN Country Group } \\
\hline Country & $\begin{array}{c}\text { Hypothesized } \\
\text { number of CEs }\end{array}$ & $\begin{array}{l}\text { Eigen } \\
\text { value }\end{array}$ & $\begin{array}{c}\text { Likelihood } \\
\text { Ratio }\end{array}$ & $\begin{array}{c}5 \% \\
\text { Critical Value }\end{array}$ & $\begin{array}{c}1 \% \\
\text { Critical Value }\end{array}$ \\
\hline \multirow{2}{*}{ Indonesia } & None & 0.679422 & 51.15702 & 15.41 & 20.04 \\
\hline & At most 1 & 0.401061 & 15.89047 & 3.76 & 6.65 \\
\hline \multirow{2}{*}{ Philippines } & None & 0.582910 & 38.78641 & 15.41 & 20.04 \\
\hline & At most 1 & 0.313893 & 11.67836 & 3.76 & 6.65 \\
\hline \multirow{2}{*}{ Singapore } & None & 0.580962 & 37.21232 & 15.41 & 20.04 \\
\hline & At most 1 & 0.281511 & 10.24876 & 3.76 & 6.65 \\
\hline \multirow{2}{*}{ Thailand } & None & 0.693688 & 43.00012 & 15.41 & 20.04 \\
\hline & At most 1 & 0.184497 & 6.322451 & 3.76 & 6.65 \\
\hline
\end{tabular}

Table 4. The estimated equations have been formulated according to the equation 1 and equation 2 respectively presented in section 3.2. In the Co-integrated equation 1 (CE1 in Table 4) the dependent variable is FDI as a share of gross fixed capital formation in first differences, and in the Co-integrated equation 2 (CE2 in Table 4) the dependent variable is GDP per capita in first differences. The numbers in brackets are the t-values of the coefficients. In the EU country sample inward FDI causes economic growth only in the case of Finland. In all other country cases FDI is motivated by economic growth while there is no case of a bidirectional relationship between inward FDI and economic growth. A similar situation is indicated for the ASEAN country sample. For all countries tested inward FDI is motivated by domestic economic growth. There is some indication of a bidirectional relationship in the case of Indonesia. 
Table 4. VECM Estimations

\begin{tabular}{|c|c|c|c|c|c|}
\hline \multicolumn{6}{|c|}{ I) EU Country Group } \\
\hline \multirow{2}{*}{$\begin{array}{c}\text { Country } \\
\begin{array}{c}\text { Error } \\
\text { correction }\end{array}\end{array}$} & \multicolumn{5}{|c|}{ Co-int 1(CE 1) Co-int 2(CE 2) } \\
\hline & D(FDI) & D(GDP) & & (CE 1) & (CE 2) \\
\hline \multirow[t]{9}{*}{ Austria } & -3.621900 & 39.97505 & R-squared & 0.799912 & 0.125550 \\
\hline & $(0.79240)$ & $(78.8459)$ & Adj. R-squared & 0.758227 & -0.056627 \\
\hline & $(-4.57082)$ & $(0.50700)$ & Sum sq. resids & 267.3810 & 2647310 . \\
\hline & & & S.E. equation & 3.337795 & 332.1213 \\
\hline & & & Log likelihood & -75.38032 & -213.3860 \\
\hline & & & Akaike AIC & 2.587477 & 11.78786 \\
\hline & & & Schwarz SC & 2.867717 & 12.06810 \\
\hline & & & Mean dependent & 0.338333 & 14.52833 \\
\hline & & & S.D. dependent & 6.788222 & 323.0992 \\
\hline \multirow[t]{9}{*}{ Denmark } & -1.756719 & 21.40973 & R-squared & 0.737108 & 0.528125 \\
\hline & $(0.54696)$ & $(13.0805)$ & Adj. R-squared & 0.682339 & 0.429817 \\
\hline & $(-3.21177)$ & $(1.63677)$ & Sum sq. resids & 5674.286 & 3245196. \\
\hline & & & S.E. equation & 15.37623 & 367.7180 \\
\hline & & & Log likelihood & -121.2057 & -216.4405 \\
\hline & & & Akaike AIC & 5.642503 & 11.99149 \\
\hline & & & Schwarz SC & 5.922742 & 12.27173 \\
\hline & & & Mean dependent & -0.412333 & 15.57067 \\
\hline & & & S.D. dependent & 27.28149 & 486.9763 \\
\hline \multirow[t]{9}{*}{ Finland } & -0.054982 & 92.17890 & R-squared & 0.766746 & 0.303330 \\
\hline & $(0.35403)$ & $(30.6468)$ & Adj. R-squared & 0.718151 & 0.158190 \\
\hline & $(-0.15530)$ & $(3.00778)$ & Sum sq. resids & 1000.785 & 7499314. \\
\hline & & & S.E. equation & 6.457504 & 558.9914 \\
\hline & & & Log likelihood & -95.17829 & -229.0050 \\
\hline & & & Akaike AIC & 3.907342 & 12.82912 \\
\hline & & & Schwarz SC & 4.187582 & 13.10936 \\
\hline & & & Mean dependent & -0.716333 & 3.379667 \\
\hline & & & S.D. dependent & 12.16344 & 609.2537 \\
\hline \multirow[t]{9}{*}{ Italy } & -1.261397 & 125.9828 & R-squared & 0.599991 & 0.208597 \\
\hline & $(0.43019)$ & $(74.3504)$ & Adj. R-squared & 0.516656 & 0.043721 \\
\hline & $(-2.93219)$ & $(1.69445)$ & Sum sq. resids & 47.54774 & 1420294. \\
\hline & & & S.E. equation & 1.407535 & 243.2672 \\
\hline & & & Log likelihood & -49.47621 & -204.0458 \\
\hline & & & Akaike AIC & 0.860537 & 11.16518 \\
\hline & & & Schwarz SC & 1.140776 & 11.44542 \\
\hline & & & Mean dependent & 0.005667 & 10.34233 \\
\hline & & & S.D. dependent & 2.024562 & 248.7661 \\
\hline \multirow[t]{9}{*}{ Germany } & -3.192647 & -15.19650 & R-squared & 0.788543 & 0.110098 \\
\hline & $(0.71299)$ & $(22.7906)$ & Adj. R-squared & 0.744489 & -0.075298 \\
\hline & $(-4.47785)$ & $(-0.66679)$ & Sum sq. resids & 2053.558 & 2098240 . \\
\hline & & & S.E. equation & 9.250130 & 295.6800 \\
\hline & & & Log likelihood & -105.9601 & -209.8993 \\
\hline & & & Akaike AIC & 4.626132 & 11.55541 \\
\hline & & & Schwarz SC & 4.906371 & 11.83565 \\
\hline & & & Mean dependent & -0.214333 & 5.403000 \\
\hline & & & S.D. dependent & 18.29968 & 285.1396 \\
\hline
\end{tabular}


Table 4. VECM Estimations (continued)

\begin{tabular}{|c|c|c|c|c|c|}
\hline \multicolumn{6}{|c|}{ I) EU Country Group } \\
\hline \multirow[t]{9}{*}{ Sweden } & -1.784685 & -6.778027 & R-squared & 0.677871 & 0.321586 \\
\hline & $(0.42426)$ & (7.33228) & Adj. R-squared & 0.610760 & 0.180250 \\
\hline & $(-4.20661)$ & $(-0.92441)$ & Sum sq. resids & 15064.01 & 4499450 . \\
\hline & & & S.E. equation & 25.05329 & 432.9862 \\
\hline & & & Log likelihood & -135.8512 & -221.3422 \\
\hline & & & Akaike AIC & 6.618867 & 12.31827 \\
\hline & & & Schwarz SC & 6.899106 & 12.59851 \\
\hline & & & Mean dependent & -0.736000 & 17.59833 \\
\hline & & & S.D. dependent & 40.15654 & 478.2263 \\
\hline
\end{tabular}

\section{II) ASEAN Country Group}

\begin{tabular}{|c|c|c|c|c|c|}
\hline Country & Coint 1 (CE 1) & Coint 2 (CE 2) & & & \\
\hline Error correction & D(FDI) & D(GDP) & & (CE 1) & (CE 2) \\
\hline \multirow[t]{9}{*}{ Indonesia } & -1.083154 & -17.73551 & R-squared & 0.763439 & 0.395214 \\
\hline & $(0.24521)$ & $(9.64917)$ & Adj. R-squared & 0.714155 & 0.269217 \\
\hline & $(-4.41718)$ & $(-1.83804)$ & Sum sq. resids & 173.3365 & 268398.0 \\
\hline & & & S.E. equation & 2.687444 & 105.7509 \\
\hline & & & Log likelihood & -68.87871 & -179.0536 \\
\hline & & & Akaike AIC & 2.154037 & 9.499029 \\
\hline & & & Schwarz SC & 2.434277 & 9.779268 \\
\hline & & & Mean dependent & 0.243333 & 3.879667 \\
\hline & & & S.D. dependent & 5.026597 & 123.7057 \\
\hline \multirow[t]{9}{*}{ Philippines } & -2.246322 & -3.643836 & R-squared & 0.831479 & 0.505011 \\
\hline & $(0.36900)$ & $(13.8986)$ & Adj. R-squared & 0.796370 & 0.401888 \\
\hline & $(-6.08764)$ & $(-0.26217)$ & Sum sq. resids & 170.4125 & 241767.4 \\
\hline & & & S.E. equation & 2.664680 & 100.3675 \\
\hline & & & Log likelihood & -68.62352 & -177.4862 \\
\hline & & & Akaike AIC & 2.137024 & 9.394534 \\
\hline & & & Schwarz SC & 2.417264 & 9.674773 \\
\hline & & & Mean dependent & -0.430000 & -1.451667 \\
\hline & & & S.D. dependent & 5.905062 & 129.7782 \\
\hline \multirow[t]{9}{*}{ Singapore } & -1.911500 & 63.89506 & R-squared & 0.746890 & 0.582947 \\
\hline & $(0.43326)$ & (42.3302) & Adj. R-squared & 0.694159 & 0.496061 \\
\hline & $(-4.41194)$ & (1.50944) & Sum sq. resids & 3370.764 & 32176547 \\
\hline & & & S.E. equation & 11.85110 & 1157.881 \\
\hline & & & Log likelihood & -113.3936 & -250.8514 \\
\hline & & & Akaike AIC & 5.121697 & 14.28555 \\
\hline & & & Schwarz SC & 5.401937 & 14.56579 \\
\hline & & & Mean dependent & 0.353333 & -12.89767 \\
\hline & & & S.D. dependent & 21.42943 & 1631.079 \\
\hline \multirow[t]{9}{*}{ Thailand } & -1.271346 & 16.54435 & R-squared & 0.801085 & 0.303992 \\
\hline & $(0.34276)$ & (19.1518) & Adj. R-squared & 0.759645 & 0.158990 \\
\hline & $(-3.70916)$ & $(0.86385)$ & Sum sq. resids & 352.9868 & 1102050 . \\
\hline & & & S.E. equation & 3.835073 & 214.2866 \\
\hline & & & Log likelihood & -79.54665 & -200.2404 \\
\hline & & & Akaike AIC & 2.865233 & 10.91148 \\
\hline & & & Schwarz SC & 3.145473 & 11.19172 \\
\hline & & & Mean dependent & 0.070000 & 16.18267 \\
\hline & & & S.D. dependent & 7.822521 & 233.6654 \\
\hline
\end{tabular}




\section{Conclusions}

The findings confirm that economic growth of the host country motivates inward FDI in both developed and developing economies. On the contrary, both hypotheses that inward FDI supports the economic growth and that there is a bidirectional relationship between economic growth and inward FDI in the recipient country receive weak confirmation, and in case any one of the two is displayed it is peculiar to individual countries rather than a general condition. The empirical results show only one country in the EU sample, namely Finland exhibiting FDI induced economic growth, and no case of a bi-directional relationship. In the ASEAN country sample there is some indication of a bi-directional relationship between economic growth and FDI only in one country, namely Indonesia and no case of FDI induced economic growth.

Within a regional economic association countries converge with respect to the stage of economic growth, hence they acquire common economic structures and policies leading FDI country patterns to also converge subject to similar dynamics. Therefore, the relationship mode between FDI and economic growth is expected to be rather similar across the country members of the regional economic integration structure. In both country samples of our investigation, i.e. the EU and the ASEAN given that natural resources are rather scarce limiting FDI exploiting such assets, economic systems are rather developed around an export oriented and outward looking strategy, and economic policies and macro organization are all designed and implemented aiming at reducing transaction costs and refining the function of markets. These commonalities leave only size, market size in particular to differentiate between countries, and inward FDI reacts to such differences, all other sets of determinants being rather converged. Market size relates to economies of scale, the latter benefiting efficiency, thus motivating efficiency seeking inward FDI. Efficiency seeking FDI is a type of FDI related to both the third and even more the fourth stages of economic growth stages, stages which ASEAN countries are going through while the EU countries are either in stage four or stage five. Increasing market size caused by rising national incomes improves the potential of taking advantage of economies of scale, hence it improves efficiency, and, finally, it induces FDI inflows. Efficiency seeking FDI is also induced by the regional integration process that raises advantages to multinationals from building regionally integrated production and marketing networks. At the same time, countries in the fifth stage of economic growth are involved in strategic asset 
seeking FDI.

In any case, the empirical findings of the paper are in line with the results of the main stream theoretical and empirical analysis, which argues in favour of Growth induced FDI , and they cast some doubt on newer findings supporting the argument that FDI induces economic growth or this of a bi-directional relationship between FDI and economic growth. However, both the eclectic paradigm and the IDP analytical framework are able to interpret the finding of the current empirical investigation, which show that the FDI-economic growth causal relationship are country path dependent and idiosyncratic.

Received 1 May 2011, Revised 30 May 2011, Accepted 7 June 2011

\section{References}

Abadir, Karim M and Taylor, A. M. (1999), "On the Definitions of Co-integration" Journal of Time Series Analysis, 20(2).

Akinlo, A. (2004), "Foreign direct investment and growth in Nigeria: An empirical investigation", Journal of Policy Modeling, 26, 627-639.

Al-iriani M. Al-shamsi F. (2007), "Foreign Direct Investment and Economic Growth in the GCC Countries A Causality Investigation Using Heterogeneous Panel Analysis", Discussion Papers.

Arellano, M., and Bond, S. R. (1991), "Some Tests of Specification for Panel Data: Monte Carlo Evidence and an Application to Employment Equations", Review of Economic Studies, 58, 277-297.

Bahraumahah, A.Z and M.A. Thanoon. (2006), "Foreign Capital flow and economic growth in East Asian Countries", China Economic Review, 17 (2006) 70-83.

Barro, R J. (1991), "Economic Growth in a Cross Section of Countries", Quarterly Journal of Economics, 106(2), pp. 407-443.

Barro, R J., and Xavier Sala-i-martin. (1995), Economic Growth, McGraw-Hill, Boston.

Barro, R. J. and X. Sala-i-martin. (1995), Economic Growth, New York: McGraw-Hill.

Bengoa, M. and Blanca Sanchez-robles. (2003), "Foreign direct investment, economic freedom and growth: new evidence from Latin America", European Journal of Political Economy, Vol. 19 (2003) 529-545

Bhasin, A., Jun, K. and P. Economu. (1994), "Assessing the Sustainability of Foreign Direct Investment Flows", World Bank, International Economics Department.

Buckley, P. J. and Casson, M. (1976), "The Future of the Multinational Enterprise", MacMillan, London.

Buckley, P. J., J. Clegg, and C. Wang. (2002), "The impact of inward FDI on the performance of Chinese manufacturing firms," Journal of International Business Studies, 33(4), 637-655. 
Caves R. (1996), "Multinational enterprises and Economic analysis", $2^{\text {nd }}$ edition. Cambridge. MA Cambridge University Press.

Caves, R. E. (1971), "International Corporations: the Industrial Economics of Foreign Investment", Economica, February.

Coase, H. (1937), The nature of the firm, Economica, IV, pp. 386-405.

Cochrane H. J. and Sbordone A. "Multivariate estimates of the permanent components of GNP and stock prices", Journal of economic dynamics and control 12(1988), 255296.

De Mello, L. R., Jr. (1997), "Foreign direct investment in developing countries: A selective survey", Journal of Development Studies, 34(1), 1-34.

Demello, L.R., Jr. (1999), "Foreign direct investment-led growth: Evidence from time series and panel data", Oxford Economic Papers, 51(1), 133-151.

Dickey, D. A., Jansen, D. W. and Thornton, D. C. (1991), "A Primer on Cointegration with An Application to Money and Income", Review Federal Reserve Bank of ST. Louis, 73.

Dickey, D. A., and Fuller. W.A. (1981), "Likelihood ratio statistics for autoregressive time series with unit root", Econometrica, 49(4), 1057-1072.

Dunning J. (1979), "Explaining changing patterns of international production: In support of the eclectic theory", Oxford Bulletin of Economics and Statistics, vol. 41(4), pp. 269-296.

Dunning, J. (1977), "Trade, location of economic activity and the multinational Enterprise: A search for an eclectic approach", in Ohlin B. (ed.), The International allocation of economic activity, London: Macmillan, Chapter 12, pp. 395-418.

Dunning, J. (1980), “Toward an Eclectic Theory of International Production: Some Empirical Test", Journal of International Business Studies, vol. 11, pp. 9-31.

Dunning, J. H. (1981), "International Production and the Multinational Enterprise", London: Allen\&Unwin.

Dunning, J. H. (1986), “The Investment Cycle Revisited”, Weltwirtschaftliches Archiv, 122, pp. 667-77.

Dunning, J. H. (1988), “Explaining International Production", London: Unwin Hyman.

Dunning, J. (1993), "Multinational Enterprise and the Global Economy", Addison Wesley, Wokingham, Berks.

Dunning, J., (1997), “The European Internal Market Programme and Inbound Foreign Direct Investment», Part I , Journal of Common Market Studies, 35(1), pp. 1-30.

Dunning, J. (2001), "The Eclectic (OLI) Paradigm of international Production: Past, Present and Future", International Journal of Economics and Business, 8(2), pp. 173190.

Engle R.E and Granger C.W.J. (1987), "Cointegration and error correction-Representation, estimation and testing”, Econometrica, 55, pp. 251-276.

Engle, R. F. and Yoo, B.S., (1987), "Forecasting and Testing in Cointegrated Systems", Journal of Econometrics, 35, 143-59.

European economy. Data on GDP series 
Eurostat : Department of FDI. Data on FDI inflows.

Granger C.W.J. (1986), "Developments in the study of cointegrated economic variables", Oxford Bulletin of Economics and Statistics, 48(3).

Granger, C. W. J. (1969), "Investigating causal relations by econometric models and cross-spectral methods", Econometrica, 35, 424-438.

Granger, C. W, J. (1980), "Long memory relationships and the aggregation of dynamic models", Journal of Econometrics, 14, 227-38.

Granger, C.W. J., (1981), "Some properties of time series data and their use in econometric model specification", Journal of Econometrics, 16, 121-30.

Hall S. G. (1989), "Maximum likelihood Estimation of cointegration vectors: An example of the Johansen procedure", Oxford bulletin economics and statistics, 51(2).

Hendry F. (1986), "DAVID Econometric modelling with cointegrated variables : An overview. Oxford bulletin economics and statistics, 48(3).

Holtz-eakin, Douglas, WHITNEY NEWEY, AND HARVEY S. ROSEN. (1988), "Estimating Vector Autoregressions with Panel Data," Econometrica 56, No. 6, November, pp. 1371-1395.

Hood, N. and Young, S. (1979), "The Economics of Multinational Enterprise”, Longman, London.

Hsiao, C. (2003), “Analysis of Panel Data”, Cambridge: Cambridge University Press.

Hymer, S. H. (1976), "The International Operations of National Firms: A Study of Direct Foreign Investment", MIT Press, Cambridge, MA.

Im, K.S., Pesaran, M.H., SHIN, Y. (2003), "Testing for unit roots in heterogeneous panels", Journal of Econometrics, 115, 53-74.

"International Monetary Fund : Balance of Payments Department of FDI", Data on FDI inflows.

Johansen Soren. (1992), "Determination of co-integration rank in the presence of a linear trend", Oxford Bulletin of Economics and Statistics, 54(3).

Johansen Soren. (1988), "Statistical analysis of co-integration vectors", Journal of Economic Dynamics and Control, North Holland, 231-254.

Kindleberger, C. P. (1969), "American Business Abroad", Yale University Press.

Krämer W. "Fractional integration and the Augmented Dickey-Fuller test", Economics Letters 61 91988, 269-272.

Maddala G.S. and In-moo KIM. (1998), "Unit roots. Co-integration and structural Change", Cambridge University Press.

Markusen, J. R. and Venables, A. J. (1999), "Foreign Direct Investment as a Catalyst for Industrial Development", European Economic Review, 43, pp. 335-56.

Narula Rajneesh. (1996), "Multinational Investment and Economic Structure. Globalisation and Competitiveness", Routledge, London and New York.

Osterwald-lenum M. (1992), "A note with Quantiles of the Asymptotic Distribution of the Maximum Likelihood Cointegration Rank Test Statistics", Oxford Bulletin of Economics and Statistics, 54(3).

Rivera batiz, F. and Rivera batiz, L. (1990), "The Effects of Direct Foreign Investment in 
the Presence of Increasing Returns due to Specialization", Journal of Economic Development, 342, pp. 287-307.

Stock H. James and Watson W. Mark (1998), "Variable trends in economic time-series", Journal of Economic Perspectives, 2(3).

United Nations: World Investment Report. various issues.

Zhang K.H. (1999), "FDI and economic growth:evidence from ten East Asian Economies”, Economia Internationale, 11(4), pp. 517-535. 